\title{
Pola Interaksi Simbolik Dan Pewarisan Kesenian Jaran Kepang Semarangan Berbasis Agil Di Era Disrupsi
}

\author{
Eny Kusumastuti ${ }^{1}$, Indriyanto ${ }^{2}$, Kusrina Widjajantie ${ }^{3}$ \\ Universitas Negeri Semarang, \\ Jln. Sekaran-Gunungpati, Semarang 50229 Indonesia \\ enykusumastuti@mail.unnes.ac.id
}

Jaran Kepang Semarangan merupakan salah satu kesenian tradisional kerakyatan yang ada di wilayah Kabupaten Semarang. Pola interaksi simbolik dan pewarisan pertunjukan Jaran Kepang memiliki keunikan tersendiri dalam menghadapi berbagai tantangan di era disrupsi ini. Penelitian ini mengkaji 1) Pola interaksi simbolik dalam pertunjukan Kesenian Jaran Kepang Semarangan di era disrupsi, 2) Pola pewarisan Kesenian Jaran Kepang Semarangan di era disrupsi. Tujuan penelitian mendiskripsikan dan menarik sebuah konsep atau teori terkait dengan pola interaksi simbolik dan pewarisan Kesenian Jaran Kepang Semarangan di era disrupsi. Lokasi penelitian di Paguyuban Langen Budi Sedyo Utomo Dusun Sombron Desa Tlompakan Kecamatan Bawen Kabupaten Semarang. Metode penelitian kualitatif dengan pendekatan etnokoreologi dan sosiologi. Teknik pengumpulan data meliputi observasi, wawancara dan dokumentasi. Keabsahan data menggunakan kriteria dependabilitas dan konfirmabilitas dengan teknik triangulasi sumber, teori dan teknik. Analisis data melalui tahapan pengumpulan data, reduksi data, penyajian data dan simpulan data. Teori yang digunakan untuk menganalisis interaksi simbolik yakni milik Herbert Mead. Temuan penelitian meliputi 1) pola interaksi simbolik antara penari dengan penari, penari dengan pemusik, penari dengan penonton, pemusik dengan penonton dan penonton dengan penonton dan 2) pola pewarisan Kesenian Jaran Kepang Semarangan di era disrupsi mengacu skema AGIL yaitu adaptasi, pencapaian tujuan, integrasi dan latensi. Pertama, dalam proses adaptasi, pola-pola kesenian Jaran Kepang Semarangan beradaptasi dengan perkembangan jaman di era modern seperti sekarang ini dengan melihat kebutuhan masyarakat. Kedua, dalam proses pencapaian tujuan, kelompok kesenian Jaran Kepang Semarangan harus memiliki tujuan dalam pelestarian di era modern. Ketiga, dalam proses integrasi, kesenian Jaran Kepang Semarangan dapat mengintegrasikan kelompok masyarakat pelaku, pendukung dan penikmat secara tidak langsung. Keempat, dalam proses latensi, kelompok Kesenian Jaran Kepang Semarangan tetap menjaga dan melestarikan kesenian Jaran Kepang Semarangan di era modern.

Kata kunci : Jaran Kepang Semarangan, Interaksi simbolik, pewarisan, era disrupsi

\section{Symbolic Interaction Patterns And Heritage Arts Jaran Kepang Semarangan Agil-Based In Erruption}

Jaran Kepang Semarangan is one of the popular traditional arts in Semarang Regency. The symbolic interaction pattern and inheritance of the Jaran Kepang show have their own uniqueness in facing various challenges in this era of disruption. This study examines 1) the pattern of symbolic interactions in the performance of arts Jaran Kepang Semarangan in the era of disruption, 2) The pattern of inheritance of Arts Jaran Kepang Semarangan in the era of disruption. The purpose of this research is to describe and draw a concept or theory related to the symbolic interaction patterns and the inheritance of Arts Jaran Kepang Semarangan in the era of disruption. The research location was in the community of Langen Budi Sedyo Utomo, Sombron Hamlet, Tlompakan Village, Bawen District, Semarang Regency. Qualitative research methods with ethnochoreology and sociology approaches. Data collection techniques include observation, interview and documentation. The validity of the data uses dependability and confirmability criteria with source triangulation techniques, theories and techniques. Data analysis through the stages of data collection, data reduction, data presentation and data conclusions. The theory used to analyze symbolic interactions is that of Herbert Mead. Research findings include 1) symbolic interaction patterns between dancers and dancers, dancers with musicians, dancers with spectators, musicians with spectators and spectators with spectators and 2) inheritance patterns of Arts Jaran Kepang Semarangan in the era of disruption referring to the AGIL scheme namely adaptation, goal attainment, integration and latency. First, in the process of adaptation, the patterns of Arts Jaran Kepang Semarangan adapt to the development of the era in the modern era as it is today by looking at the needs of the communi- 
ty. Second, in the process of achieving goals, the Jaran Kepang Semarangan art group must have a goal of preservation in the modern era. Third, in the process of integration, the art of Jaran Kepang Semarangan can indirectly integrate community groups of actors, supporters and connoisseurs. Fourth, in the latency process, the Jaran Kepang Semarangan Art group continues to maintain and preserve the Jaran Kepang Semarangan art in the modern era.

Keywords : Jaran Kepang Semarangan, Symbolic Interactions, inheritance, disruption era

Proses Review : 18 - 31 Agustus 2020, Dinyatakan Lolos: 7 September 2020

\section{PENDAHULUAN}

Jaran Kepang merupakan pertunjukan yang menggunakan anyaman yang terbuat dari bambu maupun kulit yang melompat-lompat menirukan gerak kuda. Pigeud (1983: 347) menyatakan bahwa tari Kuda tersebut merupakan pertunjukan yang mengempit anyaman yang dibuat dari bambu atau kulit, menirukan kuda atau orang yang menunggang kuda. Ciri khas Jaran Kepang sebagai properti kesenian ini, memiliki bentuk yang saling berbeda di setiap daerah, tetapi tetap menggambarkan seekor kuda yang dibuat dari anyaman bambu. Bentuk koreografi dan variasi-variasi garap penyajian pada kesenian Jaran Kepang, setiap daerah juga berbeda-beda (Sumaryono 2011: 142).

Kesenian Jaran Kepang masih tumbuh subur di wilayah kabupaten Semarang dengan jumlah 206 paguyuban/sanggar Kesenian Jaran Kepang yang tersebar di 235 kelurahan/desa. Paguyuban/sanggar tersebut masih aktif berlatih dan mengadakan kegiatan pementasan-pementasan dan mengikuti festival. Fenomena tersebut menunjukkan bahwa masyarakat Kabupaten Semarang masih menyukai dan melestarikan Kesenian Jaran Kepang di era disrupsi ini. Keberadaan Kesenian Jaran Kepang di Kabupaten Semarang tidak terlepas dari pola pendidikan seni berbasis masyarakat meliputi pelatihan, manajemen dan pendampingan (Kusumastuti 2018: 85).

Keberadaan Kesenian Jaran Kepang Semarangan dipengaruhi perkembangan teknologi yang begitu cepat menyerbu di semua lini kehidupan masyarakat modern. Era kehidupan yang serba canggih dengan gaya hidup milenial lebih dikenal dengan era disrupsi. Barometer peradaban itu kini melaju dengan cepat dalam bingkai Revolusi Industri 4.0 (Industrial Revolution 4.0). Gempuran di berbagai ranah dan kepungan teknologi yang serba disruptif, mulai dari Internet of Things (IoT), big data, otomasi, robotika, komputasi awan, hingga inteligensi artifisial (Artificial Intelligence) berhasil menorehkan penandaan besar dalam sejarah: angka 4.0 di belakang revolusi industri. Sejalan dengan penamaan itu, teknologi informasi dan komunikasi (ICT) yang merambah di semua lekuk kehidupan diyaki- ni sanggup merubah tatanan yang lebih besar, baik dalam domain hukum, sosial-budaya, ekonomi, maupun politik. Perubahan dalam segala lini kehidupan memunculkan tantangan bagi masyarakat dalam menyikapi perubahan yang terjadi di tengah-tengah jargon yang khas melekat bersama teknologi tinggi yaitu "smart, fast, efficient, sustainable" (Widayanto 2018). KR Henald Kasali (2017: 34) menyatakan bahwa disruption adalah sebuah inovasi, yang akan menggantikan seluruh sistem lama dengan cara-cara baru. Disruption berpotensi menggantikan pemain-pemain lama dengan yang baru. Disruption menggantikan teknologi lama yang serba fisik dengan teknologi digital yang menghasilkan sesuatu yang benar-benar baru dan lebih efisien, juga lebih bermanfaat.

Permasalahan yang muncul adalah bagaimanakah pola interaksi simbolik dan pewarisan Kesenian Jaran Kepang Semarangan di era disrupsi? Tujuan penelitian ini adalah 1) menganalisis, mendiskripsikan dan menyusun konsep/ teori tentang pola interaksi simbolik dan pewarisan kesenian Jaran Kepang Semarangan di era disrupsi. Hasil penelitian bermanfaat untuk pengembangan, pembinaan dan penguatan potensi kesenian tradisional di Kabupaten Semarang.

Kesenian tradisional kerakyatan tidak terlepas dari gempuran era globalisasi. Kesenian tradisional kerakyatan merupakan bagian dari kebudayaan. Kesenian tercipta dari akal dan budi manusia yang diungkapkan dengan penuh keindahan, karena pada dasarnya manusia senang dengan keindahan sehingga seni juga merupakan hasil karya cipta dari jiwa dan pikiran manusia. Kesenian berisi perangkat-perangkat model yang digunakan oleh masyarakat pendukungnya dengan bertindak secara selektif untuk berekreasi dan berapresiasi dalam rangka memenuhi kebutuhan estetikanya (Rohidi 2000:115).

Kesenian merupakan bentuk ekspresi masyarakat. Eksistensi kesenian sebagai sarana sosial bagi masyarakat untuk saling berbagi cerita dan berkumpul memupuk rasa persaudaraan, sehingga banyak kelompok-kelompok atau paguyuban yang terbentuk dari kesenian. Seiring berjalannya waktu membuat jaman semakin modern serta kecang- 
gihan teknologi informasi semakin cepat sehingga ikut berdampak pada perubahan dalam masyarakat. Kini kesenian bukan hanya sebagai media ekspresi bagi masyarakat semata, namun sudah berkembang menjadi industri pariwisata yang menjanjikan. Seperti yang disampaikan Abdullah (1981:8-12) bahwa bentuk seni adalah komunikatif. Seni adalah satu dari berbagai cara untuk mengomunikasikan sesuatu. Seniman berkarya bertujuan menularkan dan mengomunikasikan kesan dan pengalaman subjektif yang berharga kepada audience. Ini bermula dari imaginasi kreatif yang dituangkan ke dalam suatu bentuk yang ber isi , sehingga tersamar dalam satu kesatuan analisis tentang kesadaran dan realitas.

Perkembangan teknologi yang begitu cepat mempengaruhi pola-pola interaksi simbolik dalam kehidupan masyarakat. Herbert Mead menjelaskan asumsi dasar interaksi simbolik meliputi: manusia bertindak terhadap benda berdasarkan arti yang dimilikinya (pemikiran), (2) asal-muasal arti atas benda-benda tersebut muncul dari interaksi sosial yang dimiliki seseorang (bahasa), (3) makna yang demikian ini diperlakukan dan dimodifikasikan melalui proses interpretasi yang digunakan oleh manusia dalam berurusan dengan benda-benda lain yang diterimanya (pemaknaan). Teori Interaksi simbolik memusatkan perhatian pada dampak dari makna dan simbol prilaku dan interaksi manusia. Mead, sebagai tokoh teori interaksi simbolik, membedakan perilaku manusia menjadi prilaku lahiriah dan perilaku tersembunyi. Perilaku tersembunyi adalah proses berpikir yang melibatkan simbol dan arti, sedangkan prilaku lahiriah adalah prilaku sebenarnya yang nampak dan dapat diamati. Perilaku tersembunyi itulah yang menjadi perhatian utama teori interaksi simbolik (Ritzer, Doglas, 2010: 293 dalam Semasara 2019: 82).

Fenomena berupa simbol-simbol yang bisa ditangkap dan dimaknai di masyarakat merupakan refleksi dari fenomena interaksionisme simbolis. Pemaknaan tersebut didasarkan pada pemaknaan atas sesuatu yang dihadapinya lewat proses yang oleh Blumer disebut self-indication. Proses self-indication adalah proses komunikasi pada diri individu yang dimulai dari mengetahui sesuatu, menilainya, memberinya makna, dan memutuskan untuk bertindak berdasarkan makna tersebut (George 2012: 632-633). Blumer (dalam Griffin 2003) mengutarakan bahwa ada tiga prinsip utama interaksionisme simbolik, yaitu pemaknaan (meaning), bahasa (language), dan pikiran (thought). Pemaknaan (meaning) muncul sebagai akibat manusia bertindak atau bersikap terhadap manusia yang lainnya pada dasarnya dilandasi atas pemaknaan yang dikenakan kepada pihak lain tersebut.

Pemaknaan muncul dari interaksi sosial yang dipertukarkan di antara manusia. Makna bukan muncul atau melekat pada sesuatu atau suatu objek secara alamiah. Makna tidak bisa muncul 'dari sananya'. Makna berasal dari hasil proses negosiasi melalui penggunaan bahasa (language) - dalam perspektif interaksionisme simbolik. Interaksionisme simbolik menggambarkan proses berpikir (thought) sebagai perbincangan dengan diri sendiri. Proses berpikir ini sendiri bersifat refleksif. Menurut Mead (Griffin 2003) bahwa sebelum manusia bisa berpikir, membutuhkan bahasa. Manusia perlu untuk dapat berkomunikasi secara simbolik. Bahasa pada dasarnya ibarat software yang dapat menggerakkan pikiran manusia.

Perkembangan teknologi demikian dahsyat juga harus diimbangi dengan pola-pola konservasi seni budaya sehingga kesenian tradisional tetap eksis di tengah-tengah masyarakat pencipta, pelaku dan penikmat. Menurut Parson (Ritzer 2012: 408) masyarakat agar tetap eksis dalam mempertahankan keberadaannya harus dapat melakukan fungsi-fungsi atau memenuhi kebutuhan-kebutuhan sebagai sebuah sistem. Ada empat fungsi penting yang mutlak dibutuhkan bagi semua sistem sosial, meliputi (A) adaptasi (adaptation), (G) pencapaian tujuan (goal-attainment), (I) integrasi (integration), (L) latent-patern-maintenance yang selanjutnya dikenal dengan skema AGIL.

\section{METODE PENELITIAN}

Metode penelitian yang digunakan adalah kualitatif dengan pendekatan semiotik dan sosiologi. Interaksi simbolik dianalisis dengan menggunakan teori interaksionisme simbolik Blumer (dalam Griffin 2003) mengutarakan bahwa ada tiga prinsip utama interaksionisme simbolik, yaitu pemaknaan (meaning), bahasa (language), dan pikiran (thought). Untuk mengkaji pola pewarisan dianalisis dengan menggunakan teori fungsionalisme struktural Parson diawali dengan empat skema penting mengenai fungsi untuk semua sistem tindakan, skema tersebut dikenal dengan sebutan skema AGIL (adaptation, goal-attainment, integration, latentpatern-maintenance). Teknik pengumpulan data menggunakan observasi, wawancara dan dokumentasi. Keabsahan data menggunakan kriteria dependabilitas dan konfirmabilitas dengan teknik triangulasi sumber, teori dan teknik. Analisis data melalui tahapan pengumpulan data, reduksi data, penyajian data dan simpulan data.

\section{ANALISIS DAN INTEPRETASI DATA}

\section{Pola Interaksi Simbolik Kesenian Jaran Kepang Sema- rangan di Era Disrupsi}

Kesenian Jaran Kepang memiliki keistimewaan tersendiri yaitu adanya adegan trance (kesurupan) yaitu fenomena masuknya roh pepundhen atau danyang ke dalam tubuh penari. Selain trance, kesenian Jaran Kepang juga mengandung simbol-simbol yang melekat dalam setiap elemen pertunjukannya. Simbol-simbol tersebut dibentuk dari proses aksi interaksi antara pemain dengan pawang, pemain dengan pemain, pemain dengan pengiring, pemain dengan penonton, pengiring dengan penonton. Proses interaksi simbolik terbentuk karena pada hakekatnya manusia adalah makhluk yang berinteraksi, tidak hanya melalui 
interaksi secara ekslusif antar manusia, tetapi juga inklusif dengan seluruh mikrokosmos. Terkadang manusia dalam interaksi sosialnya disadari atau tidak, sering menampakkan fenomena-fenomena yang berupa simbol-simbol dan mempunyai banyak pemaknaan yang beragam antar individu.

Pola interaksi antara pemain dengan pawang terlihat pada pola pelembagaan ritual. Pola pelembagaan kesenian ritual itu sesungguhnya masih mewarisi budaya primitif yang bersifat mistis maupun magis. Seperti tari yang menirukan binatang atau animal mime atau animal dance pada masyarakat primitif sampai sekarang masih dapat ditelusuri peninggalannya. Soedarsono (dalam Minarto, 2007: 81) menjelaskan bahwa Jathilan/ jaran kepang dari Jawa dan Sanghyang Jaran dari Bali diperkirakan merupakan salah satu warisan jenis tarian ritual dari budaya purba/primitif. Kedua tarian itu menirukan gerak-gerik perilaku binatang kuda. Ketika tarian itu sedang intrance/possessed atau kalap/ndadi (bahasa Jawa), yaitu kerasukan roh; kemungkinan yang masuk ke tubuh penari adalah roh binatang totem yang berujud kuda. Hal itu dapat diamati dari gerak-gerik perilaku penarinya yang seperti binatang kuda, misalnya makan rumput dan padi, minum air comberan, dan sebagainya. Di lain pihak, perilaku penari yang kalap itu akan membentuk image magis ketika ia makan bunga, kemenyan menyala atau bersifat akrobatik, seperti makan beling, memecah kelapa dan sebagainya. Dengan magis kekuatan supranatural tersebut, jaran kepang di Jawa dalam hubungannya dengan upacara ritual berfungsi sebagai kekuatan, keselamatan desa. Hal ini menunjukkan bahwa ada pola interaksi simbolik antara penari dengan pawang. Ritual merupakan suatu bentuk upacara yang berhubungan dengan beberapa kepercayaan atau agama dengan ditandai oleh sifat khusus yang menimbulkan rasa hormat yang luhur dalam arti merupakan pengalaman suci (O Dea, 1995:5-36). Pengalaman tersebut mencakup segala sesuatu yang dibuat dan dipergunakan oleh manusia untuk menyatakan hubungan dengan alam transendental yang aplikasinya berupa suguh pada danhyang/sing mbahurek$s a$ desa. Hubungan atau perjumpaan tersebut bukan merupakan sesuatu yang umum atau biasa, tetapi sesuatu yang bersifat khusus dan istimewa sehingga manusia membuat sesuatu cara yang pantas guna melaksanakan hubungan atau pertemuan tersebut. Inti dari ritual kepercayaan/ keyakianan/agama merupakan ungkapan permohonan atau rasa syukur kepada yang dihormati atau yang berkuasa . Oleh karena itu upacara ritual diselenggarakan pada waktu yang khusus, tempat yang khusus perbuatan yang luar biasa dengan dilengkapi berbagai peralatan ritus yang bersifat sakral (dalam bahasa Jawa dinamakan ubarampen sesaji). Pada umumnya, masyarakat menerima bahwa orang yang paling dekat dengan punden adalah pawang/dukun jaran kepang. Hal itu diterima karena dukun atau pawang jaran kepang selalu memiliki kelebihan kekuatan batin. Pawang adalah orang yang dipercaya dan memiliki kekuatan supranatural sehingga dapat berkomunikasi langsung dengan alam transendental. Oleh karena itu, kedudukan pawang dalam hal ini memiliki fungsi ganda. Pertama, sebagai penyelaras keseimbangan dan kemapanan. Kedua, sebagai sarana komunikasi antara warga masyarakat dengan alam bawah sadar yang fungsinya untuk meminta. Permintaan warga bermacam-macam sesuai dengan kebutuhan, misalnya meminta keselamatan desa, meminta jodoh, meminta sembuh, bahkan meminta kaya. Sedangkan, hubungan antara dukun/pawang dengan pengendang dan penari bersifat struktural emosional sekalipun lunak.

Pola interaksi antara penari dengan penari ditunjukkan mulai dari proses persiapan dengan latihan bersama, pelaksanaan pementasan dan setelah pementasan. Penari adalah penari senior yang rata-rata memiliki ilmu-ilmu yang bersifat tertutup. Secara konvensional, penari akan mendapat julukan roh yang biasa memasuki raga penari tersebut. Tidak setiap penari dapat kemasukan roh, sehingga pada saat penari senior kemasukan roh maka penari lainnya dengan cepat menyelesaikan tariannya.

Pola interaksi antara pengiring dan penari juga terjadi bahkan menjadi bagian penting dalam sebuah pertunjukan. Pengendang dan penari merupakan orang yang dipercaya dapat menerusjalankan warisan tradisional. Hal itu dapat dimengerti karena hidup matinya pertunjukan jaran kepang terletak pada pengendang yang mengikuti dan memberdaya hidupkan pertunjukan. Pengendang yang dipercaya memegang fungsi kendali dalam ritual ditentukan oleh pawang, yaitu orang yang cukup berpengalaman dan berusia lanjut, apalagi jika kendangannya bagus. Oleh karena itu, pengendang itu dinamai pengendang Tuwek (tua/berusia lanjut). Akan tetapi seiring dengan era disrupsi, pengendang sekarang ini bisa dilakukan oleh siapapun tidak memandang dari sudut usia. Pengendang yang menentukan pola gerak penari baik dalam tahapan tari bentuk maupun dalam kondisi kesurupan roh. Setiap ditembangkan Lagu "sluku-sluku bathok" dan "slompret-slompret" penari mulai kesurupan (Irawan 2016). Setiap bunyi kendang keras, gerak penari juga keras para penari lari dan saling mengejar. Penari ndadi dengan gerakan yang tidak terkendali saling berlarian didiringi dengan gamelan yang cepat. Saron berbunyi keras mulai mengubah tempo lebih pelan.

Pola Interaksi antara penonton dengan iringan pada saat pertunjukan dimulai, setelah musik dimainkan para pemusik/penabuh menandakan penari akan keluar. Gendhing yang menandakan tari Gejawan dibunyikan, para penonton sudah mulai mendekat untuk menyaksikan. Penonton mulai mencari tempat untuk menyaksikan pertunjukan. Beberapa penonton ada yang cepat-cepat mencari tempat untuk mencari tempat yang nyaman dan teduh. Penonton ada yang menikmati gendhing sedikit menggoyangkan badan. Pola Interaksi penari dengan penonton terjadi pada saat penari sedang ndadi atau kesurupan. Penari yang sedang ndadi bisa berlari tidak terkendali dan menubruk sia- 
pa saja yang ada di depannya tidak terkecuali penonton. Dan anehnya, penonton yang ditubruk akan ikutan ndadi atau kesurupan.

Pola Pewarisan Kesenian Jaran Kepang Semarangan Berbasis AGIL (Adaptation, Goal-attainment, Integration, Latent-patern-maintenance)

Pengembangan kesenian tradisional kerakyatan diperlukan untuk mengikuti perkembangan iptek di era disrupsi, meskipun demikian tidak boleh melampaui batas kewajaran dan harus tetap mempertahankan nilai-nilai luhur budaya bangsa. Selama ini masyarakat secara swadaya merawat dan mengembangkan kesenian Jaran Kepang tersebut hingga tetap bertahan dan tetap dimainkan (Pahlevi 2016: 2). Pelestarian dan pewarisan sebuah kesenian tradisional kerakyatan dilakukan oleh masyarakat pencipta, masyarakat pelaku dan masyarakat penikmat melalui proses latihan, pengembangan dan pentas rutin. Proses pewarisan dilakukan melalui pembelajaran alih ide, nilai, serta keterampilan. Pola pewarisan Kesenian Jaran Kepang Semarangan sebagai di era disrupsi mengacu skema AGIL (Adaptation, Goal-attainment, Integration, Latent-patern-maintenance) yaitu adaptasi, pencapaian tujuan, integrasi dan latensi.

Pertama, dalam proses adaptasi, pola-pola kesenian Jaran Kepang Semarangan dalam beradaptasi dengan perkembangan jaman di era modern seperti sekarang ini dengan melihat kebutuhan masyarakat. Pelembagaan jaran kepang dengan masyarakat penikmat secara administratif, dijalankan oleh pengurus yang strukturnya sangat sederhana dan bersifat fleksibel terbuka, cukup ada ketua, sedangkan sekretaris, bendahara, seksi-seksi penunjang dilaksanakan secara gotong-royong oleh siapa saja yang siap. Hal itu terjadi karena pelembagaan jaran kepang tidak bersifat profit oriented, akan tetapi lebih bersifat kenikmatan, pemuasan diri, dan tanggung jawab terhadap kelangsungan tradisi desa. Oleh karena itu, jika pentas atau diminta main, yang dibicarakan pertama bukan honorariumnya, melainkan seberapa luas lapangan permainan dan seberapa jauh lokasi dari desa. Hal itu dipakai sebagai pedoman untuk menentukan jumlah peserta yang ikut. Jaran kepang tersebut milik masyarakat desa sehingga anggotanya pun adalah masyarakat Desa yang tidak perlu mendaftarkan diri dan tidak pernah ditanyakan kartu anggotanya. Itu sebabnya jika diminta main, bukan honorarium yang diutamakan, tetapi dapat menampung berapa pemain dan penoton. Dalam kenyataannya, perilaku berkesenian pedesaan bukan lahan profesionalisme lebih-lebih mata pencaharian, tetapi lebih berfungsi kebutuhan rohaniah dan pencerahan.

Perkembangan teknologi di era disrupsi membawa perubahan peradaban kehidupan masyarakat baik dalam kehidupan sehari-hari ataupun dalam berkesenian. Munculnya era disrupsi berdampak pada pola interaksi simbolik dan pewarisan kesenian Jaran Kepang Semarangan. Dampak positif perkembangan teknologi memberikan kemudahan bagi masyarakat dalam mengakses berita-berita pertunjukan, jadwal pementasan dan sebagai media sosialisasi hanya cukup melalui gagdet saja sehingga kesenian Jaran Kepang semakin populer di tengah-tengah masyarakat pendukungnya. Kesenian Jaran Kepang yang dikenal oleh masyarakat umum, semakin mengakar kuat pada masyarakat pencipta, pelaku dan pendukungnya. Kemudahan akses yang diberikan perkembangan teknologi menguntungkan masyarakat untuk lebih mudah berkomunikasi dalam tempo yang singkat dan cepat sehingga lebih efektif baik dari segi biaya, waktu dan tenaga. Dampak negatif perkembangan teknologi yang begitu cepat membuat masyarakat menjadi lebih bersifat individual.

Pola adaptasi dengan perkembangan jaman saat ini juga dilakukan melalui media sosial dengan munculnya grupgrup Watshap, Facebook setiap paguyuban atau grup yang memaparkan jadwal pementasan, grup Facebook Reog'r yang mewadahi seluruh pecinta, pelaku dan penonton jaran kepang dari berbagai daerah dan secara rutin setiap minggu memaparkan jadwal pementasan jaran kepang dari setiap paguyuban.

Kedua, dalam proses pencapaian tujuan, kelompok kesenian Jaran Kepang Semarangan harus memiliki tujuan dalam pelestarian di era modern. Hal ini ditunjukkan dengan munculnya kesepakatan bersama secara tidak tertulis bahwa tujuan kelompok jaran kepang bukan hanya sekedar mencari keuntungan semata melainkan lebih pada keinginan untuk berekspresi dan meneruskan tumbuh kembangnya kesenian Jaran Kepang di Kabupaten Semarang.

Ketiga, dalam proses integrasi, kesenian Jaran Kepang Semarangan dapat mengintegrasikan kelompok masyarakat pelaku, pendukung dan penikmat secara tidak langsung. Proses integrasi Kesenian Jaran Kepang di Kabupaten Semarang ditunjukkan adanya sebuah grup Facebook Reog'r yang dibuat untuk menampung dan menyatukan kelompok masyarakat pelaku, pendukung dan penikmat secara bersama-sama melestarikan kesenian Jaran Kepang.

Keempat, dalam proses latensi, kelompok Kesenian Jaran Kepang Semarangan tetap menjaga dan melestarikan kesenian Jaran Kepang Semarangan di era modern. Proses pelestarian Cavalli-Sforza dan Feldman dalam Adhiputra (2013: 43) menyatakan:Terdapat dua jenis system pewarisan yakni "Vertical Transmission" dan"Horizontal Transmission". "VerticalTransmission"(Pewarisan Tegak) ialah sistem pewarisan yang berlangsung melalui mekanisme genetik yang diturunkan dari waktu ke waktu secara lintas generasi yakni melibatkan penurunan ciri-ciri budaya dari orang tua kepada anak-cucu. Dalam pewarisan tegak, orang tua mewariskan nilai, keterampilan, keyakinan, motif budaya,dan sebagainya kepada anak-cucu mereka. Oleh karena itu pewarisan tegak disebut juga "BiologicalTransmission" yakni sistem pewarisan yang bersifat biologis. 
Pola pewarisan ini terjadi dalam kesenian Jaran Kepang di Kabupaten Semarang, para orang tua mengajarkan pada anak cucu mereka serta melibatkan dalam setiap pementasan kesenian Jaran Kepang.

"Horizontal Transmission" (Pewarisan Miring) ialah sistem pewarisan yang berlangsung melalui lembaga-lembaga pendidikan seperti sekolah-sekolah atau sanggar-sanggar. "Horizontal Transmission" terjadi ketika seseorang belajar dari orang dewasa atau lembaga lembaga (misalnya dalam pendidikan formal) tanpa memandang apakah hal itu terjadi dalam budaya sendiri atau dari budaya lain. Sistem pewarisan vertikal hanya mengandalkan mekanisme genetik (keluarga atau saudara) dalam proses pewarisannya. Generasi tua berperan sebagai guru yang mewariskan aturan-aturan, keterampilan, ide-ide dan sebagainya. Sistem pewarisan vertikal ini hanya dilakukan pada orang-orang yang masih mempunyai hubungan darah atau sering disebut dengan biological transmission.

\section{SIMPULAN}

Pola interaksi simbolik kesenian Jaran Kepang Semarangan terjadi antara penari dengan pawing, penari dengan penari, penari dengan pemusik, penari dengan penonton, pemusik dengan penonton.

Pola pewarisan Kesenian Jaran Kepang Semarangan di era disrupsi mengacu skema AGIL yaitu adaptasi, pencapaian tujuan, integrasi dan latensi. Pertama, dalam proses adaptasi, pola-pola kesenian Jaran Kepang Semarangan beradaptasi dengan perkembangan jaman di era modern seperti sekarang ini dengan melihat kebutuhan masyarakat. Kedua, dalam proses pencapaian tujuan, kelompok kesenian Jaran Kepang Semarangan harus memiliki tujuan dalam pelestarian di era modern. Ketiga, dalam proses integrasi, kesenian Jaran Kepang Semarangan dapat mengintegrasikan kelompok masyarakat pelaku, pendukung dan penikmat secara tidak langsung. Keempat, dalam proses latensi, kelompok Kesenian Jaran Kepang Semarangan tetap menjaga dan melestarikan kesenian Jaran Kepang Semarangan di era modern.

\section{DAFTAR RUJUKAN}

Abdullah, Taufik. (1980/1981). Disekitar Komunikasi Ilmu dan Seni. Analisis Kebudayaan. 2: 8-12.

Adhiputra, AnakAgung Ngurah. 2013. Konseling Lintas Budaya. Yogyakarta: Graha Ilmu.

Griffin, Emory A., (2003). A First Look at Communication Theory, 5th edition, New York: McGraw-Hill.

Irawan, Yusuf Rizki. (2016). Lagu Slompret-slompret sebagai Pemicu Trance pada Penari Jaran Kepang Turonggo Seto di Desa Tlompakan Kecamatan Tuntang Kabupaten
Semarang. Skripsi. Semarang: Pendidikan Sendratasik UNNES.

Kasali, Rhenald. (2017). Disruption. Jakarta: Gramedia.

Kusumastuti, Eny. (2018). Model Pendididkan Seni Berbasis Masyarakat Sebagai Upaya Peningkatan Daya Saing Produk Budaya Bangsa. Laporan Penelitian. Semarang: Lembaga Penelitian dan Pengabdian Kepada Masyarakat.

Minarto, Soerjo Wido. (2002). Dasar-Dasar Komposisi dan Koreografi. Malang: Universitas Kanjuruhan Malang (tidak dipublikasikan).

Minarto, Soerjo Wido. (2007). Jaran Kepang dalam Tinjauan Interaksi Sosial. Jurnal BAHASA DAN SENI, Tahun 35, Nomor 1, Februari 2007. Hal 76-87. Malang: Universitas Kanjuruhan Malang diunduh 20 September 2019 dari http://sastra.um.ac.id/wp-content/uploads/2009/10/ Jaran-Kepang-dalam-Tinjauan-Interaksi-Sosial-pada-Upacara-Ritual-Bersih-Desa.pdf

O Dea, Thomas F. (1995). Sosiologi Agama: Suatu Pengenalan Awal. Terjemahan: Yasogama. Jakarta: PT Raja Grafindo Persada

Pigeaud, Th. (1938). Javaanse Volksvertoningen: Bijdrage tot de Beschrijving van Land en Volk.alih bahasa Kanjeng Raden Tumenggung Muhammad Husodo Pringgokusumo: Volkslectuur Batavia 215.

Pahlevi, Reza dkk. (2016). Eksistensi Kesenian Jaran Kepang dalam Arus Industri Pariwisata di Dusun Suruhan Desa Keji Kabupaten Semarang. Jurnal Solidarity Jurusan Sosiologi Antropologi FIS Universitas Negeri Semarang. volume 5 no 1. Hal. 1-7. Semarang: Universitas Negeri Semarang. Diunduh 20 April 2019 dari httpseprints.uns. ac.id32194.

Ritzer, Goerge. (2011). Sosiological Theory atauTeori Sosiologi Dari Sosiologi Klasik Sampai Perkembangan Terakhir Postmodern. Terjemahan Saat Pasaribu dkk.(2012). Yogyakarta: Pustaka Belajar.

Rohidi, Tjetjep Rohendi. (2000). Kesenian Dalam Pendekatan Kebudayaan. Bandung: STISI Bandung Press.

Seramasara, I. G. N. (2019). Wayang Sebagai Media Komunikasi Simbolik Perilaku Manusia Dalam Praktek Budaya Dan Agama Di Bali. Mudra Jurnal Seni Budaya, 34(1), 80-86. https://doi.org/10.31091/mudra.v34i1.640

Sumaryono. (2011). Antropologi Tari Dalam Persepektif Indonesia. Yogyakarta: ISI Yogyakarta

Widjayanto, Febby . 2018. Menyikapi Era Disrupsi. https://news.detik.com/kolom/3926626/menyika- 
pi-era-disrupsi. 